\title{
SISTEM INFORMASI GEOGRAFIS PENATAAN RUANG DAN BANGUNAN BERBASIS WEB DI KANTOR DINAS CIPTA KARYA, TATA RUANG DAN PERUMAHAN KOTA PONTIANAK
}

\author{
Budi Santosa', Agus Sasmito Aribowo² , Fito Nichito, \\ Prodi. Teknik Informatika Fakultas Teknologi Industri \\ Universitas Pembangunan Nasional "Veteran" Yogyakarta \\ Jl. Babarsari No.2 Yogyakarta 55281 \\ email: dissan@if.upnyk.ac.id
}

\begin{abstract}
One of the functions of the Department of Human Settlement and Housing Spatial Pontianak is directly related to community planning is the provision of advice to the people who will be building in the city of Pontianak to fit the layout plan Pontianak city. However, in the delivery of planning advice, as the applicant community must come directly to the office of the Department of Human Settlements, and Housing Spatial Pontianak and front office personnel meet. This condition would reduce the efficiency of the time because they have to provide the information and explanations individually to each applicant who comes and front office personnel are still using analogue map in the form of a sheet of paper with the scale of 1:70000. Data search is still done manually by collecting it from multiple sources. Under the proposed conditions built "Geographic Information Systems and Spatial Planning Web-Based Building in the Office of Human Settlement and Housing Spatial Pontianak". The methodology used to build the "Geographic Information Systems and Spatial Building in Web-based Office of Human Settlements and Housing Spatial Pontianak" This is a method of Water Fall (waterfall cycle). Geographic information system provides time efficiency and accuracy of information in the search for a better location than using paper maps should look for the data and the location manually and provide convenience to the applicant who will erect the building for access to information about the rules and regulations of the interior of the establishment surrounding buildings Building Floor Coefficient (KLB), coefficient Building Basics (KDB) and Simpadan Line Building (GSB). This information system using ArcGIS 9.3 software to make maps, Mapscript as a module that is used to make MapServer functions and classes that can be run in PHP. As for applications using MySQL database and using the database file. Dbf of the map that was created in ArcGIS.
\end{abstract}

Keywords : KDB, KLB, GSB, advis planning, geografic information system.

Salah satu fungsi Dinas Cipta Karya, Tata Ruang dan Perumahan Kota Pontianak yang langsung berhubungan dengan masyarakat adalah pemberian advis planning kepada masyarakat yang akan mendirikan bangunan di kota Pontianak agar sesuai dengan rencana tata ruang kota Pontianak. Namun, dalam penyampaian advis planning, masyarakat sebagai pemohon harus datang langsung ke kantor Dinas Cipta Karya, Tata Ruang dan Perumahan Kota Pontianak dan menemui petugas front office. Kondisi ini tentu mengurangi efisiensi waktu karena harus memberikan informasi dan penjelasan secara perorangan kepada setiap pemohon yang datang serta petugas front office masih mengunakan peta analog dalam bentuk lembaran kertas dengan skala 1:70000. Pencarian data juga masih dilakukan secara manual dengan mengumpulkannya dari beberapa sumber. Berdasarkan kondisi yang dikemukakan maka dibangun "Sistem Informasi Geografis Penataan Ruang dan Bangunan Berbasis Web di Kantor Dinas Cipta Karya, Tata Ruang dan Perumahan Kota Pontianak". Metodologi yang digunakan untuk membangun "Sistem Informasi Geografis Tata Ruang dan Bangunan Berbasis Web di Dinas Cipta Karya Tata Ruang dan Perumahan Kota Pontianak" ini adalah metode Water Fall (siklus air terjun). Sistem informasi geografis ini memberikan efisiensi waktu dan akurasi informasi yang lebih baik dalam pencarian lokasi daripada menggunakan peta kertas yang harus mencari data dan lokasi secara manual serta memberikan kemudahan kepada pihak pemohon yang akan mendirikan bangunan untuk untuk mengakses informasi tentang aturan dan ketetapan tata ruang dalam pendirian bangunan seputar Koefisien Lantai Bangunan(KLB), Koefisien Dasar Bangunan(KDB) serta Garis Simpadan Bangunan(GSB). Sistem informasi ini menggunakan software ArcGIS 9.3 untuk membuat peta, mapscript 
sebagai modul yang digunakan untuk membuat fungsi dan class MapServer agar dapat dijalankan di PHP. Sedangkan untuk aplikasi databasenya menggunakan MySQL serta menggunakan file database .dbf dari peta yang telah dibuat di ArcGIS.

\section{Kata kunci : KDB, KLB, GSB, advis planning, sistem informasi geografis}

\section{PENDAHULUAN}

Advis planning atau Surat Keterangan Rencana Kota (SKRK) adalah informasi awal yang diterima oleh pemohon tentang rencana tata ruang kota, tata bangunan dan lingkungan yang diberlakukan oleh Pemerintah Kota Pontianak. Adapun ketentuan-ketentuan yang mendasari advis planning adalah :

1. Rencana Tata Ruang Wilayah (RTRW), yang mana mengatur peruntukan bangunan, koefisien dasar bangunan (KDB), koefisien lantai bangunan (KLB) dan lainnya.

2. Keputusan Walikota Pontianak Nomor 19 tahun 1999 tentang Petunjuk Pelaksanaan Retribusi Izin Mendirikan Bangunan, yang mana mengatur Garis Simpadan Bangunan (GSB) dan Rencana Milik Jalan (RMJ).

Untuk penyampaian advis planning, masyarakat sebagai pemohon harus datang langsung ke kantor Dinas Cipta Karya, Tata Ruang dan Perumahan Kota Pontianak dan menemui petugas front office. Kondisi ini tentu mengurangi efisiensi waktu karena harus memberikan informasi dan penjelasan secara perorangan kepada setiap pemohon yang datang. Belum lagi dalam proses penyampaian advis planning, Petugas front office masih mengunakan peta analog dalam bentuk lembaran kertas dengan skala 1:70000. Pencarian data juga masih dilakukan secara manual dengan mengumpulkannya dari beberapa sumber.

\section{DASAR TEORI}

\subsection{Data dan Informasi}

Seperti kutipan yang terdapat di dalam buku "SIG: Konsep-Konsep Dasar (Perspektif Geodesi dan Geomatika)" yang ditulis oleh Eddy Prahasta, data adalah fakta mengenai suatu objek, orang dan lain-lain yang dinyatakan oleh nilai (angka, karakter atau simbol-simbol lainnya). Sementara informasi adalah analisis dan sintesis terhadap data, atau, informasi adalah data yang telah diorganisasikan ke dalam bentuk yang sesuai dengan kebutuhan seseorang, manajer, staf atau orang lain di dalam suatu organisasi atau perusahaan (Kadir,1999).

\subsection{Sistem}

Secara umum sistem dapat didefinisikan sebagai sekumpulan objek, ide, berikut saling keterkaitannya (inter-relasi) di dalam (usaha) mencapai suatu tujuan (atau sasaran bersama tertentu). Atau dengan kata lain, sistem dapat disebutkan sebagai kumpulan komponen (subsistem fisik maupun non-fisik/logika) yang saling berhubungan satu sama lainnya dan bekerja sama secara harmonis untuk mencapai suatu tujuan (Prahasta,2009).

\subsection{Sistem Informasi}

Pada saat ini tentu saja hampir semua organisasi telah memiliki sistem informasi. Sistem informasi merupakan sebuah entitas (kesatuan) formal yang terdiri dari berbagai sumber daya fisik maupun logika. Dari organisasi ke organisasi, sumber daya ini disusun atau distrukturkan dengan beberapa cara (yang bisa jadi berlainan satu sama lainnya); karena suatu organisasi dan sistem informasi terkait merupakan sumberdaya yang bersifat dinamis (Prahasta,2009).

\subsection{Geografi}

Menurut Richthoffen, Geografi adalah ilmu yang mempelajari permukaan bumi sesuai dengan referensinya, atau studi mengenai area-area yang berbeda di permukaan bumi di dalam pengertian karakteristik-karakteristiknya. Sedangkan menurut Vidal de la Blache, geografi adalah sain mengenai tempat-tempat (places) yang sangat mengonsentrasikan diri pada kualitas-kualitas dan potensi-potensi suatu Negara (Sumaatmadja,1998).

\subsection{Sistem Informasi Geografis}

Definisi SIG (kemungkinan besar) masih berkembang, bertambah dan bervariasi. Hal ini terlihat dari banyaknya definisi SIG yang telah beredar di berbagai sumber pustaka. Lebih dari itu SIG juga merupakan suatu bidang kajian ilmu dan teknologi yang belum terlalu lama dikembangkan, digunakan oleh berbagai bidang atau disiplin ilmu, dan berkembang dengan cepat. Sehubungan dengan hal ini, sebagai ilustrasi, berikut adalah beberapa definisi SIG yang telah beredar di berbagai sumber pustaka (Prahasta,2009) : 
1. SIG adalah sistem yang terdiri dari perangkat keras, perangkat lunak, data, manusia (brainware), organisasi dan lembaga yang digunakan untuk mengumpulkan, menyimpan, menganalisis dan menyebarkan informasi-informasi mengenai daerah-daerah di permukaan bumi.

2. SIG adalah sistem komputer yang digunakan untuk memanipulasi data geografis. Sistem ini diimplementasikan dengan menggunakan perangkat keras dan perangkat lunak komputer yang berfungsi untuk: (a) akuisisi dan verifikasi data, (b) kompilasi data, (c) penyimpanan data, (d) perubahan atau updating data, (e) manajemen dan pertukaran data, (f) manipulasi data, (g) pemanggilan dan presentasi data, dan (h) analisa data.

3. SIG adalah sistem komputer yang digunakan untuk mengumpulkan, memeriksa, mengintegrasikan dan menganalisis informasi-informasi yang berhubungan dengan permukaan bumi.

4. SIG adalah kumpulan yang terorganisasi dari perangkat keras komputer, perangkat lunak, data geografi dan personil yang dirancang secara efisien untuk memperoleh, menyimpan, meng-update, memanipulasi, menganalisis dan menampilkan semua bentuk informasi yang bereferensi geografis.

\subsection{Koefisien Dasar Bangunan (KDB)}

Menurut peraturan pemerintah nomor 3 tahun 2008 tentang bangunan gedung di Kota Pontianak, Koefisien Dasar Bangunan (KDB) adalah angka persentase perbandingan antara luas seluruh lantai dasar bangunan gedung dan luas lahan / tanah perpetakan / daerah perencanaan yang dikuasai sesuai rencana tata ruang dan rencana tata bangunan dan lingkungan di kota yang bersangkutan.

\subsection{Koefisien Lantai Bangunan (KLB)}

Menurut peraturan pemerintah nomor 3 tahun 2008 tentang bangunan gedung di Kota Pontianak, Koefisien Lantai Bangunan (KLB) adalah angka persentase perbandingan antara luas seluruh lantai bangunan gedung dan luas tanah perpetakan / daerah perencanaan yang dikuasai sesuai rencana tata ruang dan rencana tata bangunan dan lingkungan di kota yang bersangkutan.

\subsection{Garis Sempadan Bangunan (GSB)}

Menurut peraturan pemerintah nomor 3 tahun 2008 tentang bangunan gedung di Kota Pontianak, Garis Sempadan Bangunan (GSB) adalah garis pada kavling yang ditarik sejajar dengan garis as jalan, tepi sungai, atau as pagar dan merupakan batas antara bagian kavling yang boleh dibangun dan yang tidak boleh dibangun.

\section{ANALISIS DAN PERANCANGAN}

\subsection{Analisa}

Dalam pengembangan sistem informasi geografis ini diperlukan suatu analisis guna membantu proses perancangan sistem. Analisis terhadap sistem kebutuhan ini terbagi menjadi tiga, yaitu :

\section{Analisis Input}

Input ataupun masukkan dalam sistem ini yang dapat dilakukan oleh admin adalah input data peta yang terdiri dari data kavling, data KDB, data KLB dan data jalan pada saat proses peng-edit-an data peta, input data undang-undang, input data kategori dan input data admin pada saat melakukan edit password. Sedangkan user hanya dapat melakukan input data kunjungan pada buku tamu.

\section{Analisis Proses}

Proses yang terdapat dalam sistem ini terbagi menjadi dua yaitu proses pada admin dan proses pada user. Pada admin proses yang terdapat yaitu proses login, proses manage undang-undang, proses manage kategori, proses lihat peta, proses edit data kavling, proses edit data peta, proses manage buku tamu, proses edit password dan proses logout. Sedangkan pada user hanya terdapat proses cari undang-undang, proses download undang-undang, proses lihat peta dan proses isi buku tamu.

\section{Analisis Output}

Output pada sistem ini terbagi menjadi dua yaitu output untuk admin dan output untuk user. Output untuk admin terdiri dari data admin, data undang-undang, data buku tamu, data kategori, data kavling, data KDB, data KLB, data jalan, data sungai, data wilayah administrasi dan data kawasan pelestarian alam. Sedangkan output untuk user terdiri dari data undangundang, nama kategori, data kawasan pelestarian alam, data wilayah administrasi, data sungai, data KDB, data KLB, data jalan dan data kavling. 


\subsection{Perancangan Sistem}

Setelah melakukan analisis dari sistem informasi geografis tersebut maka langkah selanjutnya adalah melakukan perancangan sistem untuk mengidentifikasi dari kebutuhan fungsional dalam mempersiapkan rancang bangun implementasi yang bertujuan untuk merancang dan mendesain sistem dalam memenuhi kebutuhan user yang akan menggunakan sistem.

\subsubsection{Perancangan DFD}

Pada perancangan proses akan digunakan Data Flow Diagram (DFD), dimana DFD merupakan suatu bagan yang menggambarkan asal data, tujuan penyimpanan data dan proses yang terjadi pada sistem ini. Beberapa perancangan DFD yang terdapat di dalam sistem ini, yaitu :

\section{Data Flow Diagram Level 0}

Pada DFD level 0 ini terdapat dua entitas yaitu admin sebagai pengelola sistem dan user sebagai pengguna sistem. Gambar 1 menampilkan hubungan kedua entitas pada sistem ini.

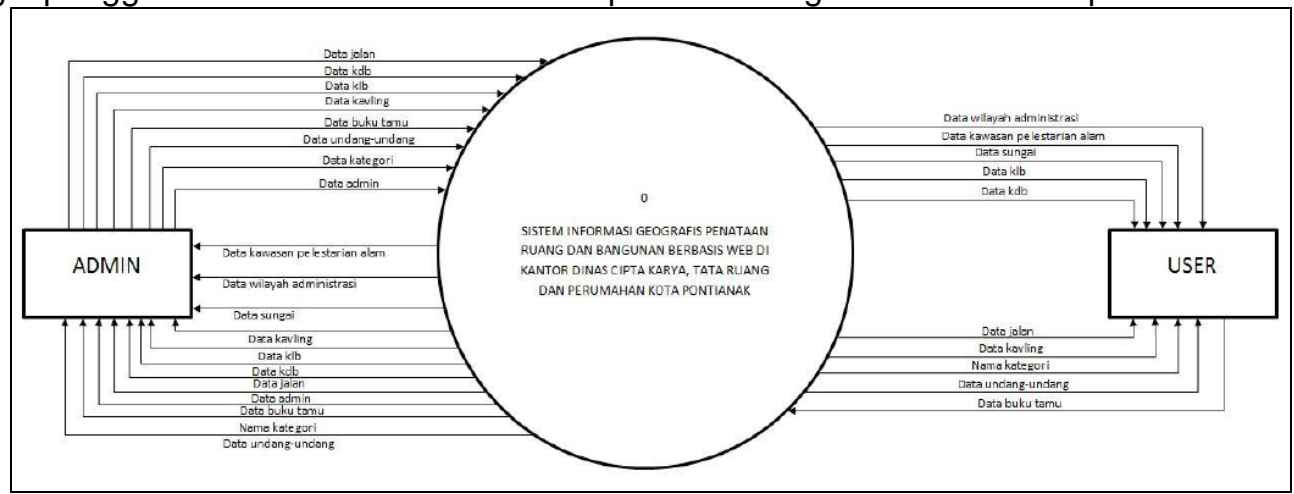

Gambar 1. DFD Level 0 SIG Penataan Ruang dan Bangunan Berbasis Web di Kantor Dinas Cipta Karya, Tata Ruang dan Perumahan Pontianak

\section{Data Flow Diagram Level 1}

DFD level 1 merupakan representasi dari data pada DFD level 0 yang sudah dipartisi untuk memberikan penjelasan yang lebih rinci. Pada DFD level 1 sistem informasi geografis penataan ruang dan bangunan berbasis web di kantor Dinas Cipta Karya, Tata Ruang dan Perumahan Kota Pontianak ini terdapat tiga proses utama yaitu proses login, layanan user dan layanan admin.

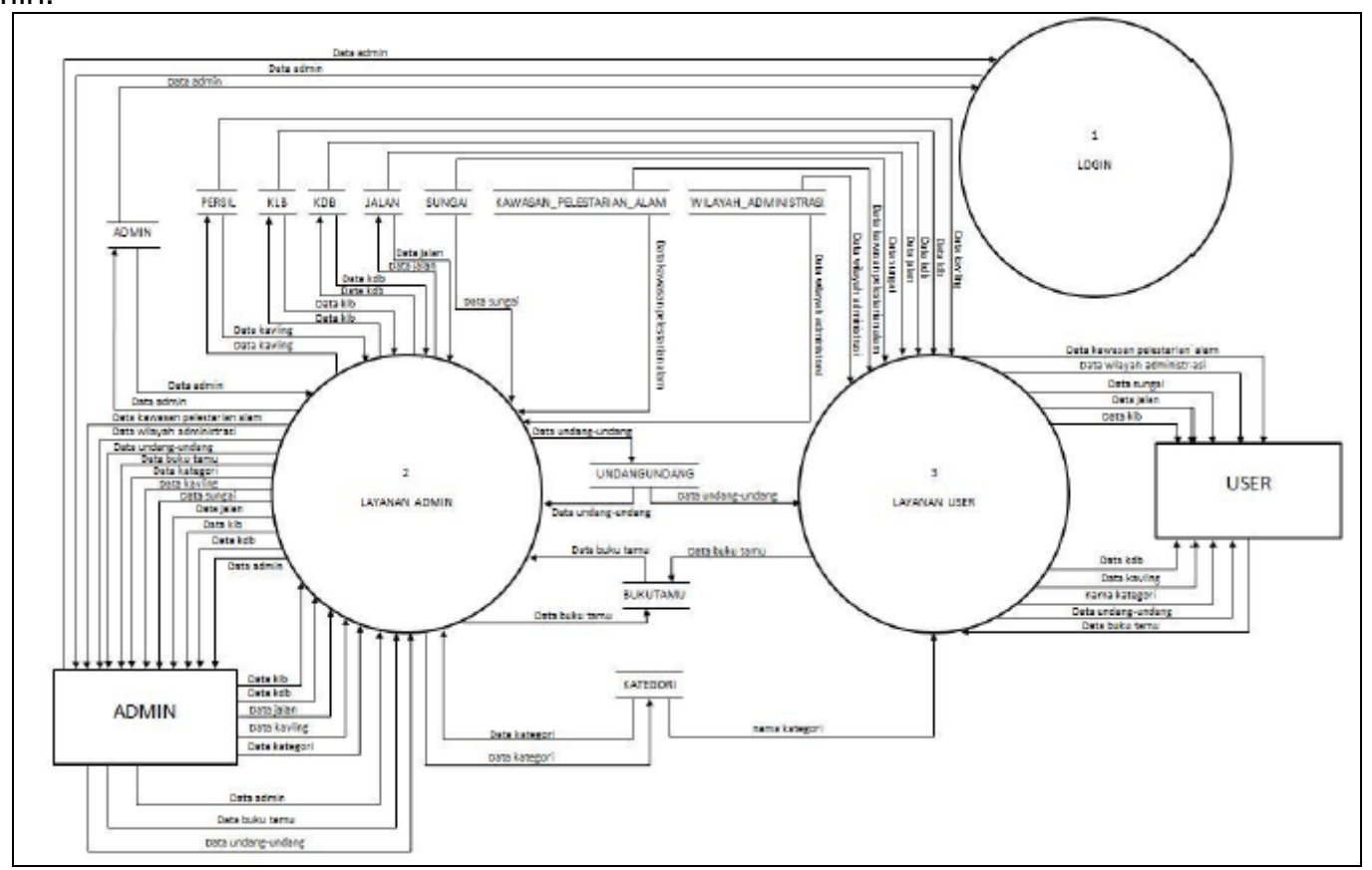

Gambar 2. DFD Level 1 SIG Penataan Ruang dan Bangunan Berbasis Web di Kantor Dinas Cipta Karya, Tata Ruang dan Perumahan Pontianak 


\subsubsection{Perancangan Basis Data}

Pada perancangan basis data digunakan dua jenis basis data yaitu basis data MySQL yang berfungsi untuk menjalankan sistem dan basis data yang memiliki format .dbf. Basis data ini berfungsi untuk menampung data masing-masing layer pada peta. Pada gambar 3 merupakan gambar rancangan ERD untuk peta.

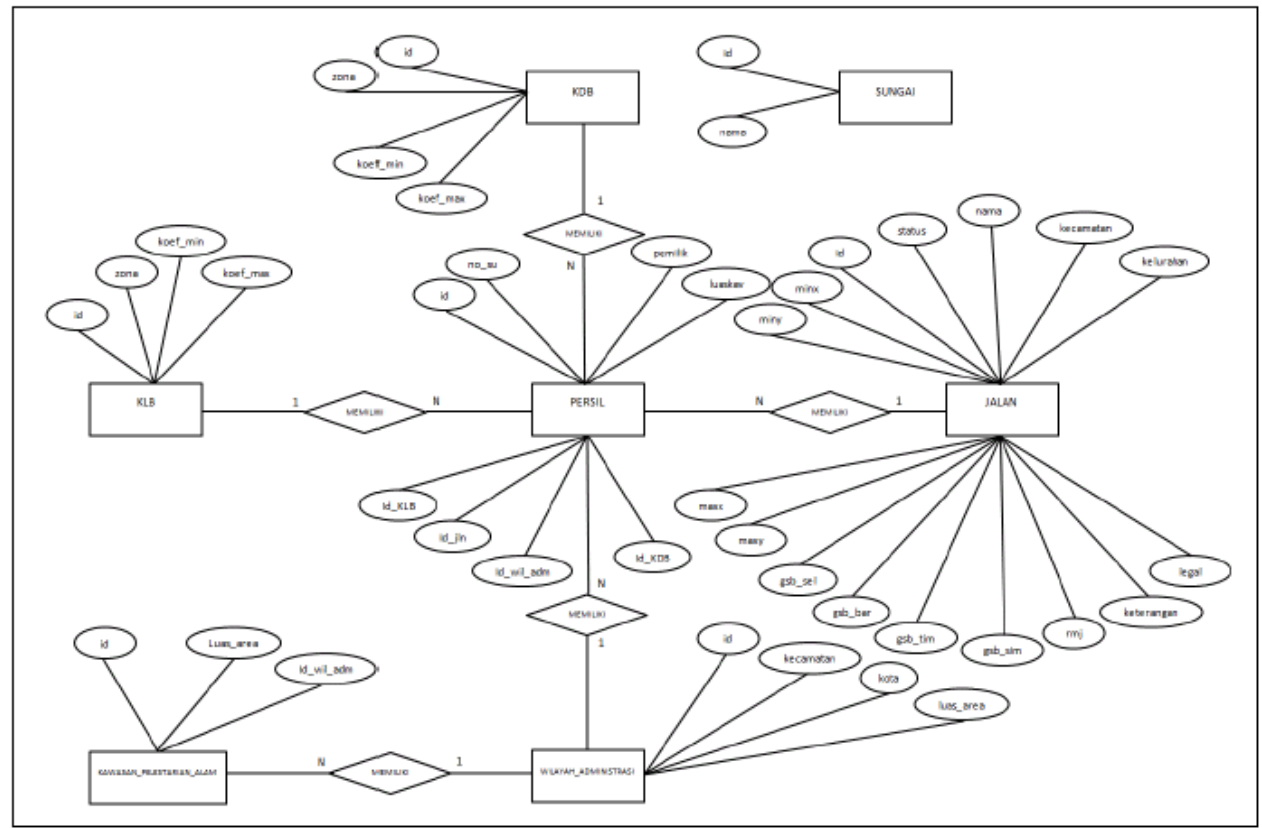

Gambar 3. Entity Relationship Diagram

\subsubsection{Hasil Perancangan}

Dari perancangan ERD (Entity Relationship Diagram), maka dapat dijabarkan tabeltabel yang diperlukan dalam sistem ini yang terdiri atas:

\section{Tabel Wilayah Administrasi}

Tabel wilayah_administrasi merupakan tabel yang digunakan untuk menyimpan data pada layer wilayah_administrasi, tabel ini berisi id wilayah administrasi, kecamatan, kota dan luas area administrasi.

\section{Tabel Koefisien Dasar Bangunan (KDB)}

Tabel KDB merupakan tabel yang digunakan untuk menyimpan data pada layer KDB, tabel ini berisi id KDB, zona, koefisien minimum KDB dan koefisien maksimum KDB.

\section{Tabel Koefisien Lantai Bangunan (KLB)}

Tabel KLB merupakan tabel yang digunakan untuk menyimpan data pada layer KLB. Tabel ini berisi id KLB, zona, koefisien minimum KLB dan koefisien maksimum KLB.

\section{Tabel Jalan}

Tabel jalan merupakan tabel yang digunakan untuk menyimpan data pada layer jalan. Tabel ini berisi id jalan, status jalan, nama jalan, kecamatan, kelurahan, GSB utara, GSB selatan, GSB barat, GSB timur, GSB simetris, RMJ, keterangan GSB, legalitas GSB, koordinat minimum $\mathrm{x}$, koordinat minimum $\mathrm{y}$, koordinat maksimum $\mathrm{x}$ dan koordinat maksimum y.

\section{Tabel Kawasan Pelestarian Alam}

Tabel kawasan_pelestarian_alam merupakan tabel yang digunakan untuk menyimpan data pada layer kawasan_pelestarian_alam. Tabel ini berisi id kawasan pelestarian alam, luas area kawasan pelestarian alam dan id wilayah administrasi. id wilayah administrasi berfungsi sebagai foreign key dari tabel wilayah_administrasi.

\section{Tabel Sungai}

Tabel sungai merupakan tabel yang digunakan untuk menyimpan data pada layer sungai. Tabel ini berisi id sungai dan nama sungai.

\section{Tabel Persil}

Tabel persil merupakan tabel yang digunakan untuk menyimpan data kavling pada layer persil, tabel ini berisi id persil, nomor surat ukur, nama pemilik kavling, luas kavling, id jalan sebagai foreign key dari tabel jalan, id KDB sebagai foreign key dari tabel kdb, id KLB 
sebagai foreign key dari tabel klb, id wilayah administrasi sebagai foreign key dari tabel wilayah_administrasi.

\section{IMPLEMENTASI}

Implementasi adalah tahap untuk menterjemahkan segala keperluan perangkat lunak kedalam bahasa yang dimengerti oleh komputer menggunakan sebuah bahasa pemrograman. Tahap ini merupakan tahap lanjutan dari tahap perancangan yang telah dilakukan sebelumnya. Dalam tahap implementasi akan dijelaskan mengenai perangkat keras (hardware) dan perangkat lunak (software) yang digunakan dalam membangun sistem ini, file-file yang digunakan dalam membangun sistem, tampilan web beserta potongan-potongan script program untuk menampilkan halaman web.

\subsection{Perangkat Keras yang Digunakan}

Perangkat keras yang digunakan dalam membangun Sistem Informasi Geografis Penataan Ruang dan Bangunan Berbasis Web di Kantor Dinas Cipta Karya,Tata Ruang dan Perumahan Kota Pontianak ini adalah :

1. Mainboard Gigabyte Z68MA-D2H-B3

2. Processor Intel(R) Core(TM) i5-3570K CPU @ 3.40GHz 3.70GHz

3. Ram $8 \mathrm{~Gb}$

4. Hardisk $40 \mathrm{~Gb}$

5. Intel(R) HD Graphic 4000

6. LG Monitor 22"

\subsection{Perangkat Lunak yang digunakan}

Perangkat lunak yang digunakan dalam membangun Sistem Informasi Geografis Penataan Ruang dan Bangunan Berbasis Web di Kantor Dinas Cipta Karya,Tata Ruang dan Perumahan Kota Pontianak :

1. Adobe Dreamweaver CS5

2. ArcGIS 9.3

3. Mozilla Firefox Browser

4. Google Chrome Browser

5. MySQL 5.0.22 \& PHP MyAdmin dengan xampp 1.7.7

6. Windows 7 ultimate $64 \mathrm{bit}$

7. Ms4w(Mapserver for Windows)

\subsection{User Interface halaman peta}

Pada implementasi halaman peta menggunakan file load_modul.php untuk menyisipkan modul mapscript, index.phtml sebagai halaman template, navigasi.php sebagai penyedia fitur untuk memudahkan user megolah peta, file rutr-layer.php untuk menampilkan daftar layer peta, form-cari.php untuk fasilitas pencarian dalam menggunakan peta dan rutr.php untuk menjalankan fungsi-fungsi pada peta.

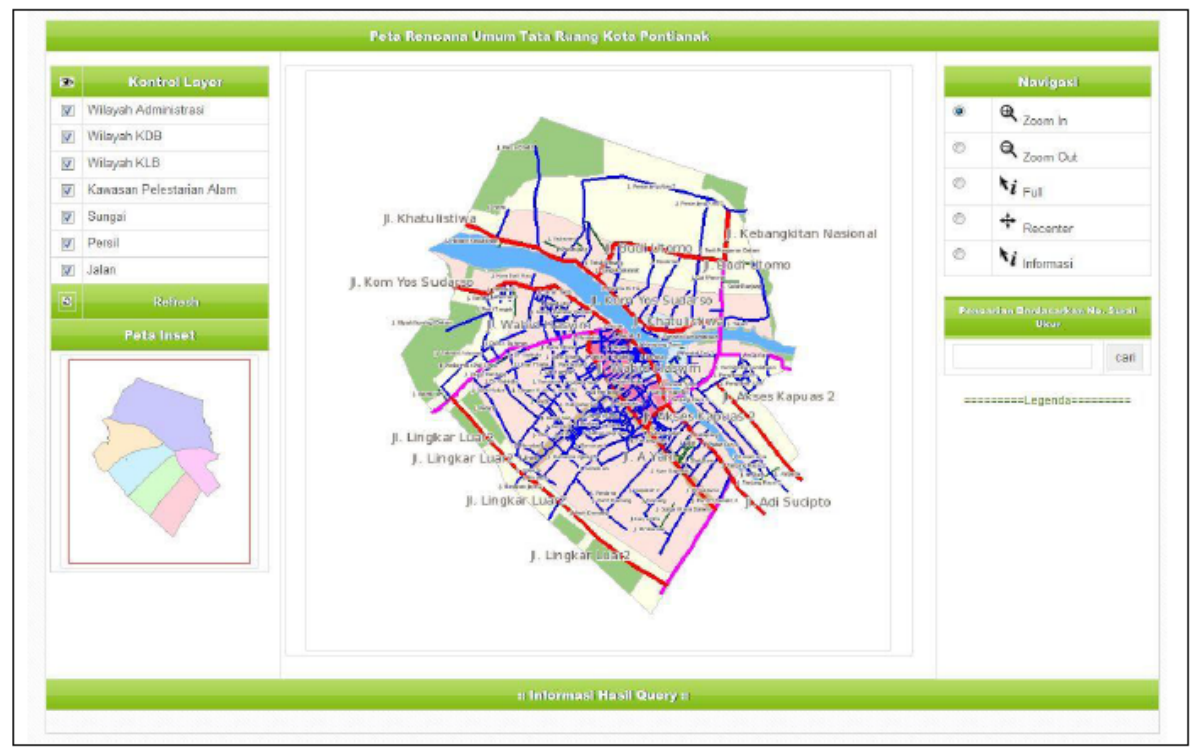

Gambar 4. Tampilah Halaman Peta 


\section{Implementasi Halaman Informasi Query}

Pada implementasi halaman informasi query digunakan file selengkapnya.php yang didalamnya terdiri dari query-administrasi.php untuk menampilkan informasi daerah administrasi, query-jalan.php untuk menampilkan informasi jalan, query-KDB.php untuk menampilkan informasi daerah KDB, query-KLB.php untuk menampilkan informasi daerah KLB, query-kpa.php untuk menampilkan informasi daerah kawasan pelestarian alam dan querypersil.php untuk menampilkan informasi kavling.

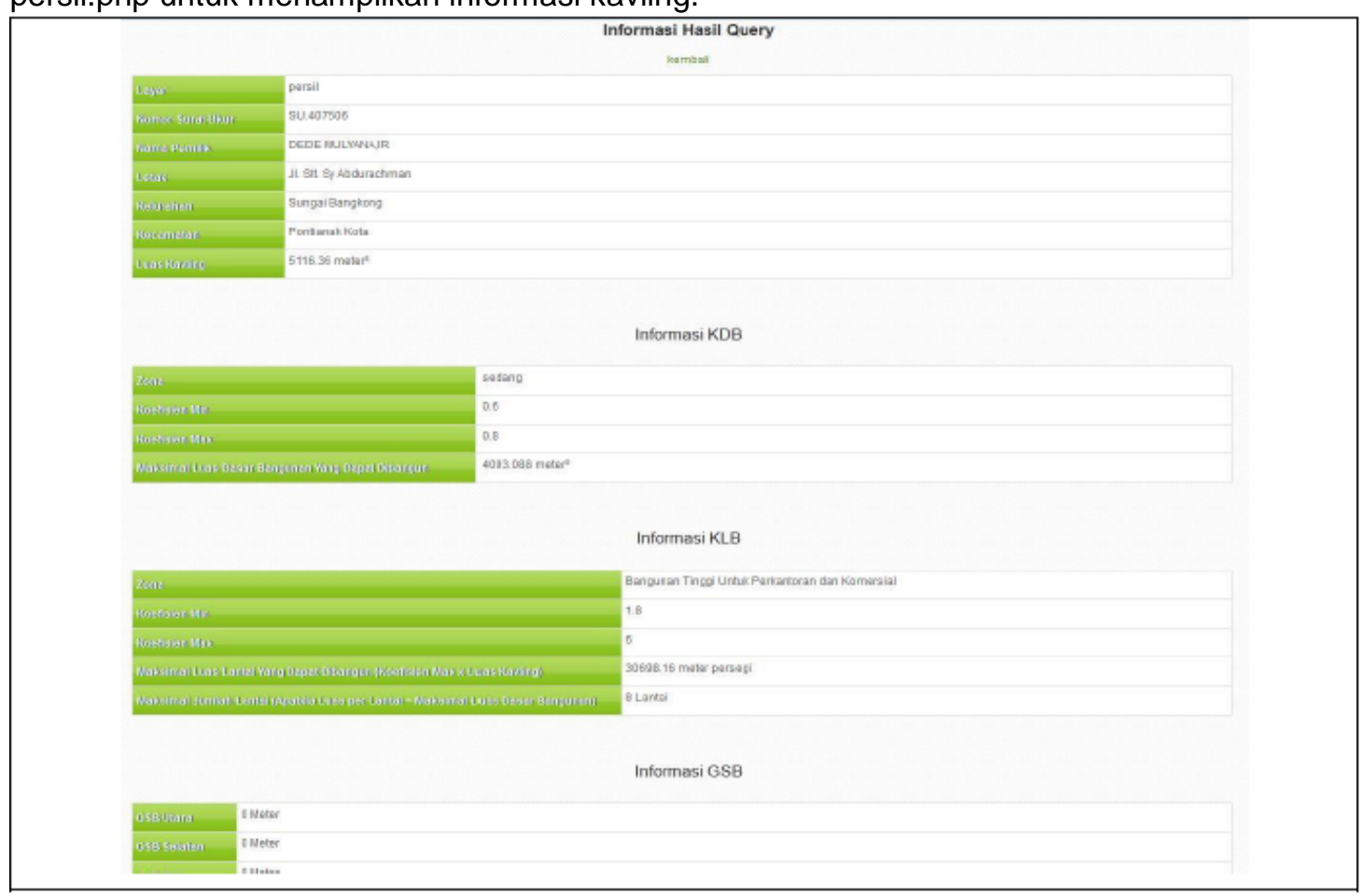

Gambar 5. Tampilan Halaman Informasi Query

\section{Implementasi Halaman Ganti File Kavling pada menu Admin}

Pada implementasi halaman gati file kavling digunakan file gantifilekavling.php untuk menampilkan form upload file kavling.

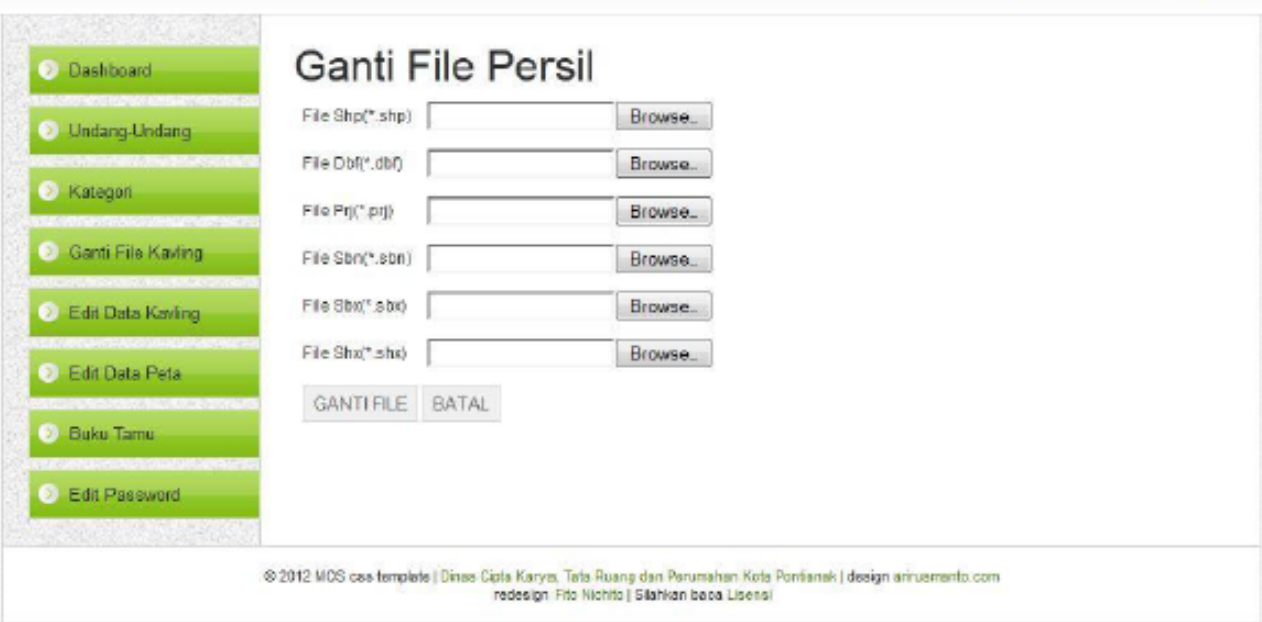

Gambar 6. Tampilan Halaman Ganti Kavling pada menu Admin 


\section{KESIMPULAN}

Berdasarkan penelitian ini, dapat diambil kesimpulan bahwa telah berhasil dibangun suatu sistem informasi geografis penataan ruang dan bangunan berbasis web di Kantor Dinas Cipta Karya, Tata Ruang dan Perumahan Kota Pontianak. Sistem yang telah dibangun dapat memudahkan user untuk memperoleh informasi mengenai advis planning secara visual melalui media internet sehingga dapat menambah efisiensi waktu dalam penyampaian advis planning serta akurasi informasi yang didapat akan jauh lebih baik daripada menggunakan peta kertas.

\section{DAFTAR PUSTAKA}

Connolly, Thomas dan Carolyn Begg., 2005, Database Systems : A Practical Approach to Design, Implementation, and Management. 4th Edition. Addison Wesley, Glasgow.

Eaglestone, B. dan Ridley, M., 2001, Web Database Systems. McGraw-Hill, New York.

McLeod, Raymond Jr. dan George P. Schell., 2004, Management Information Systems, 9th Edition, Pearson Prentice Hall, New Jersey.

Prahasta, E., 2009, SIG:Konsep-Konseop Dasar (Perspektif Geodesi dan Geomatika), Cetakan Pertama, Informatika : Bandung

Pressman, R.S., 2002, Rekayasa Perangkat Lunak Pendekatan Praktisi, Buku I, Andi : Yogyakarta

Turban, Rainer, dan Potter., 2001, Introduction to Information Technology. John Wiley \& Sons, Inc., New Jersey. 